\title{
PALAEOGEOGRAPHICAL AND ARCHAEOLOGICAL RECORDS OF NATURAL CHANGES OF THE JORDANOWO-NIESULICE SUBGLACIAL CHANNEL NEAR LUBRZA, THE LUBUSZ LAKELAND
}

\author{
Magdalena RatajczaK-Szczerba ${ }^{1}$, IwOna SobKOWiak-TabaKa ${ }^{2}$, \\ IWONA OKUNIEWSKA-NOWACZYK ${ }^{2}$ \\ ${ }^{1}$ Institute of Geoecology and Geoinformation, Adam Mickiewicz University in Poznań, Poland \\ 2Institute of Archaeology and Ethnology of the Polish Academy of Sciences, Poznań, Poland
}

Manuscript received: June 25, 2015

Revised version: August 31, 2015

\begin{abstract}
RATAJCZAK-SzCZERBA M., 2015. Palaeogeographical and archaeological records of natural changes of the Jordanowo-Niesulice subglacial channel near Lubrza, the Lubusz Lakeland. Quaestiones Geographicae 34(3), Bogucki Wydawnictwo Naukowe, Poznań, pp. 101-116, 8 figs, 3 tables. DOI 10.1515/quageo-2015-0027, ISSN 0137-477X.
\end{abstract}

AвsтRAст: The region of the Lubusz Lakeland in western Poland where there are a lot of subglacial channels provides opportunity for multi-proxy palaeoenvironmental reconstructions. None of them has not been the object of a specific study. The developmental history of the palaeolakes and their vicinity in the subglacial trough Jordanowo-Niesulice, spanning the Late Glacial and beginning of the Holocene, was investigated using geological research, lithological and geomorphological analysis, geochemical composition, palynological and archaeological research, OSL and AMS-radiocarbon dating. Geological research shows varied morphology of subglacial channel where at least two different reservoirs functioned in the end of the Last Glacial period and at the beginning of the Holocene. Mostly during the Bølling-Allerød interval and at the beginning of the Younger Dryas there took place melting of buried ice-blocks which preserved the analysied course of the Jordanowo-Niesulice trough. The level of water, and especially depth of reservoirs underwent also changes. Palynological analysis shows very diversified course of the Allerød interval.

KEYWORDS: palaeogrography, palaeoclimate, subglacial channels/trough, pollen analysis, human impact/geoarchaeology

Address of the corresponding author: Magdalena Ratajczak-Szczerba, e-mail: magdarat@amu.edu.pl; Iwona Sobkowiak-Tabaka, e-mail: iwona.sobkowiak@iaepan.poznan.pl; Iwona Okuniewska-Nowaczyk, e-mail: iwona.okuniewska@iaepan.poznan.pl

\section{Introduction}

According to many collected data from western, central and eastern Europe the Last Scandinavian Ice Sheet recession was characterized by numerous environmental oscillations. These changes were recorded in many evidences: terrestrial, glacial and marine proxy. During Late Glacial vegetation and sedimentation changed dynamically (Starkel 2002, Birks, Birks 2004, Willis, van Andel 2004, Latałowa, van der Knaap
2006, Zernitskaya et al. 2014). Changes in Europe were not synchronous. For example in the north-eastern part of Europe there was the delay of the early Holocene warming (Zernitskaya et al 2014 and referenced literature). The Łagów Lake District that lies in the Central Polish Plain in the Lubuska Pleistocene Plateau was free of ice after the Poznan Phase during the recession of the Vistulian Glaciation. Presence of the ice sheet left terrestrial glacial and fluvioglacial landforms which were transformed in the periglacial environment 
and by numerous processes being a result of early Holocene warming. This region provides opportunities for multiproxy palaeoenvironmental and palaeoclimatic reconstructions. The research fill the gap in the western part of Poland in the middle Europe. In the present study there was made an attempt to achieve more detailed knowledge on the Late Glacial and Early Holocene development of the sedimentary environment, changes of the plant cover and climatic dynamic and people density changes of settlement.

\section{Site description}

The Jordanowo-Niesulice trough $\left(52^{\circ} 19^{\prime} \mathrm{N}\right.$, $15^{\circ} 26^{\prime} \mathrm{E}, 66,25-72,5 \mathrm{~m}$ a.s.l.) is a middle size trough (subglacial valley) (Fig. 1A, B). It is $18 \mathrm{~km}$ long and its width is from 400 to $2000 \mathrm{me}-$ tres, depth - from 10 to 30 metres. The slopes are inclined at the angle $6^{\circ}-25^{\circ}$. The axis goes from NE toward SW. It is the effect of subglacial drainage. The subglacial valley cuts perpendicularly the morainic hills of different genesis: transformed morainic hills, dead ice moraines, end moraines of accumulation type. They were developed during the Poznan Stage (Phase) of the Last Scandinavian ice sheet. Erosion-denudational valleys cut the slopes of morainic hills and subglacial valley. The flat surface of the present bottom of the analysied trough lies at the altitude of 70-75 $\mathrm{m}$ a.s.l. Nowadays the trough is drained by the Paklica river in the northern course and the Niesulicki Channel in the southern course. There are some lakes in the trough in the vicinity of the research area: the Lubrza Lake, the Goszcza Lake, the Lubie Lake and the Czarny Dół Lake (Fig. 1B).

The morainic hills and moraines are built of fluvioglacial sands and gravels, glacial tills, clays and deformed glacial lake deposits with Miocene sediments. Pleistocene plateau is built of fluvioglacial sands and gravels which became from the transgression of the Vistulian glaciation (Chmal 2003). The subglacial trough is filled by peats, peats on gyttja, alluvia and sand of valley bottoms (Chmal 2003).

\section{Investigation methods}

\section{Field and laboratory work}

The geology structure of the middle course of the Jordanów-Niesulice trough was investigated using a manual Instorf corer and the Eijkelkamp hand auger. There were done 183 drillins along 26 lines. Using graphic interpolation four maps of palaeoreservoirs were made: the morphology of reservoir bottom map, the gyttja thickness map, the top (ceiling) peat thickness map and map of peat on the bottom (so called "bottom peat") distribution. The bottom of the trough is built of sand. Sand is covered by organic matter, mostly by gyttja of different types and peat - in some places it lies directly on sand and younger peat at the top of biogenic deposits. The sediment core of $713 \mathrm{~cm}$ long used in the analysis was taken using a manual Instorf corer (location of drilling at Fig 1.C, LB 2013). It reached the mineral bottom of the palaeolake. In the laboratory there were taken samples in every 2-3 cm for further studies. Detailed lithofacial analysis were taken to recognize kame situated in the investigated course of the trough. The kame was explored on the basis of three outcrops were made for lithological analysis of sediments: one in the middle of the main axis, second near the connection of the kame with trough slopes and third one along the fossil shore of the palaeoreservoir. Ground investigations consisted in basic lithological analyses: sediment types, their textural and structural characteristics were determined, palaeocurrents were measured and samples taken for laboratory analysis. Laboratory analysis and accompanying desk studies of results included the following steps: analysis of the mechanical composition of the deposits, using Casagrande's aerometric-sieve method (Racinowski, Szczypek 1985, Płochniewski 1986), an analysis of the abrasion grade of quartz grains using Krygowski's (1964) mechanical graniformametry method for the fraction of $1.0-0.8 \mathrm{~mm}$, determination of the calcium carbonate content using Scheibler's apparatus. Miall's lithofacial code, as modified by Zieliński (1992), was used for the textural-structural description of the sediments. It is very important part of the analysed trough because it is the place of very early settlement. The settlement sites were given in to archaeological research. In order to indentify the 

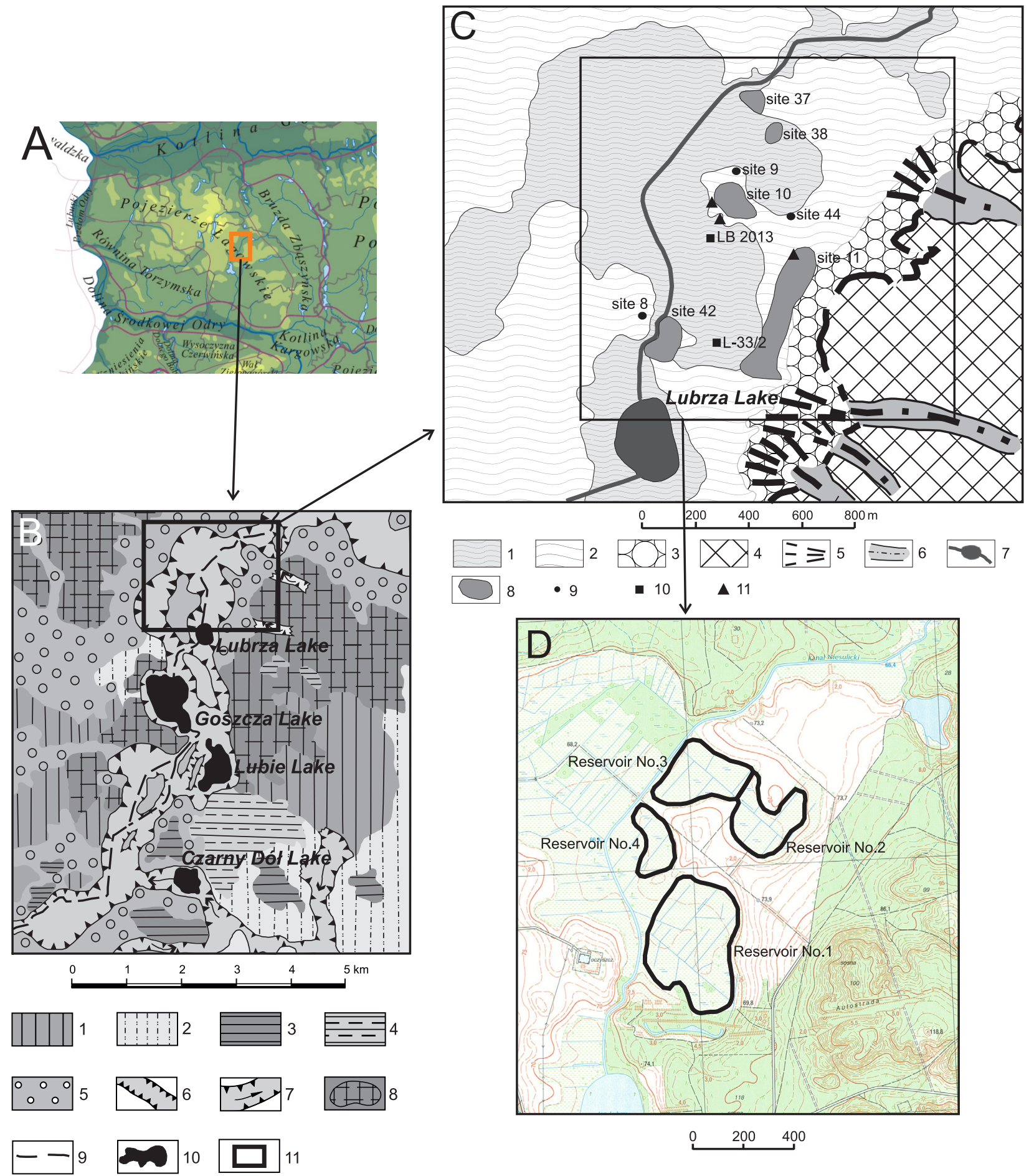

Fig. 1. Location of the research area.

A. Lubuskie Lake District Pojezierze Łagowskie, according to Kondracki (2000); B. Geomorphological map of the Jordanowo-Niesulickie glacial troughs according to Chmal (2003): 1 - flat moraine plateau, 2 - undulated and hummocky moraine plateau, 3 -end moraines, mostly accumulative, 4 - dead ice moraines, 5 - outwash plains, 6 - subglacial troughs, 7 - melt-out water valleys, 8 - transformed moraine hills, 9 - artificial channels, 10 - lakes. C. Geomorphological sketch of the research area and location of investigated sites.1-biogenic matter accumulation plain, 2 - outwash plains level (sandur), 3 - edge of subglacial channels, 4 - moraine hills, 5 - alluvial fans, 6 - erosion-denudative valleys, 7 - water reservoirs; 8 - archaeologically investigated areas; 9 - archaeologically investigated sites, 10 - location of drillings and collected cores for palynological (L-33/2 and LB 2013) and geochemical analysis (LB 2013). D. Location of investigated reservoirs (palaeolakes), 11 - location of outcrops in the kame.

content of organic matter $(\mathrm{OM})$ and terrigenous component in the sediments, loss-on-ignition (LOI) survey was applied. Sediment samples were dried at $105^{\circ} \mathrm{C}$ and combusted at $550^{\circ} \mathrm{C}$ for at least $4 \mathrm{~h}$ for the burning of organic matter. Organic matter and mineral proportions were 
determined. Two samples of mineral sediments were taken from the investigated kame for OSL

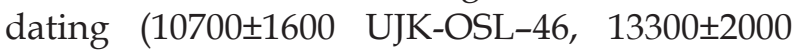
UJK-OSL-47). AMS-radiocarbon dates (11) of organic matter taken from the LB 2013 core were done (Table 1). For pollen analysis samples of fresh sediment, covering $2-3 \mathrm{~cm}$ intervals, were prepared using the standard methodology (Berglund, Ralska-Jasiewiczowa 1986). Archaeological research was lead under the methodology which is typical for palaeolithic sites. It consists in manual exploration of archaeological layers in outcrops, with using 1-meter net. Deposits from each 1 square meter were winnowed through sieves which have 1-2 cm loops, from each $10 \mathrm{~cm}$ thick mechanical layer. Artefacts from each 1 meter and layer were counted separately.

\section{Results}

\section{The geological structure}

The geology of the middle course of the Jordanów-Niesulice trough was analysed in the vicinity of archeological sites 10 (Fig. 1C, D). On the geological map this area is mark as flat surface of biogenic accumulation. It rises up to 66.25 and 68.75 meters asl. The bottom is very diversified. The maximum depth is about 9.5 - 10 meters. On the basis of geological research 4 palaeolakes were explored and they were named: first reservoir (No. 1) to the south-east from the archaeological site 10 (Fig. 1C, D), the second reservoir (No. 2) to the north-east, the third one - to the north-west and fourth - to the south-west from the site 10 (Fig. 1C, D). According to the geological evidences, the second reservoir was a separated lake. The three others could be connected. However, to confirm this thesis, there is a need of further geological investigation.

Investigated reservoirs differ in size. The biggest is reservoir No. 1. Its diameter is 400 meters long (Fig. 1D). The palaeolake No. 2 along N-S axis is 370 meters long and along W-E axis - 250 meters long. Width of the third reservoir (No. 3) is 300 meters. The smallest palaeolake is No. 4 with 150 meters width and 300 meters length. The reservoirs differ in shape. The reservoir No. 1 is almost square, No. 2 is similar the L letter. Shape of No. 3 I No. 4 reservoirs is unknown because the western shores and extend of them have not been explored do far. All drainage basins have similar depth, more than 9 meters. The reservoir No. 1 even more than 10 meters. Probably the depth is bigger because drillings have not reached the mineral bottom. The reservoir No. 2 is not so deep. Its maximum depth is 8.7 meters, up to the mineral bottom. Morphology of palaeolakes are in two of them (No. 3 \& 4) not complicated (Fig. 2). In the middle of them there are depressions. In the reservoir No. 2 there are two depressions - in the southern part of it the biggest one, and in the northern part - the smallest one. In the reservoir No. 1 the big depression is in the middle of it and in this depression there is a convex, oval bottom form that is built of sand. The ceiling of it is 2 meters under the present surface of biogenic matter. The shores are in the form of a steep slopes or gentle ones. The reservoirs are filled with gyttja of different types, with peat mostly in two positions. Gyttja occurs in several lithofacies, i.e. silty-clay,

Table 1. AMS-radiocarbone dates from the LB 2013 core.

\begin{tabular}{|c|c|c|c|c|}
\hline Lab. No. & Depth $(\mathrm{cm})$ & Dated material & ${ }^{14}$ C age (BP) & $\begin{array}{c}\text { Biostratigraphical } \\
\text { zone }\end{array}$ \\
\hline Poz-58460 & $602-606$ & Plant detritus & $8790 \pm 50$ & Holocene \\
\hline Poz-60137 & $651-652$ & Plant detritus & $10400 \pm 50$ & Younger Dryas \\
\hline Poz-60138 & $676-677$ & Plant detritus & $10660 \pm 50$ & Younger Dryas \\
\hline Poz-65350 & 668 & Plant detritus & $11160 \pm 50$ & Younger Dryas \\
\hline Poz-65346 & 693 & Plant detritus & $11220 \pm 50$ & Allerød \\
\hline Poz-58461 & 704 & Wood, Pinus needle & $11340 \pm 60$ & Allerød \\
\hline Poz-58462 & 704 & Wood, Pinus needle & $11090 \pm 60$ & Allerød \\
\hline Poz-65347 & 706 & Charcoal, Pinus & $11770 \pm 60$ & Allerød \\
\hline Poz-58463 & 707 & Charcoal, Pinus & $11760 \pm 60$ & Allerød \\
\hline Poz-58465 & 709 & Charcoal, Salix & $11700 \pm 60$ & Allerød \\
\hline Poz-58466 & $710-711$ & Plant detritus & $7970 \pm 40$ & Allerød \\
\hline Poz-61250 & 711 & Charcoal, Pinus & $11250 \pm 50$ & Allerød \\
\hline
\end{tabular}


calcareous, detritus and mineral. The mineral substrate of reservoirs are covered by silty-clay gyttja and calcareous-mineral gyttja. Gyttja is gray, beige and olive. The profiles taken along the shoreline display interbeddings of charcoals. The interbeddings of malacofauna and plants remains occure also very often. The reservoir No. 2 is filled by gyttja of quite different lithofacies. It is a silty-clay, detritus and calcareous gyttja, covering mostly the floor of the reservoir. However, it differs in colour, It is brown, rusty and even pink and pale pink. The latteris probably the effect of dead red alga Rhodophyta. Algae contain carotenoids and dyes - red - ficoeritrina and blue - phycocyanin (Podbielkowski 1975, Kordowski et al. 2014). And these dyes give unusual colour of gyttja. The thickness of gyttja reach from 5.7 meters (in the reservoir No. 2) to at least 9.3 meters (in the res- ervoir No. 1) (Fig. 3). In some places the mineral floor of reservoir are covered by peat, so called basal peat (Fig. 4). The basal peat is stated on the basis of its stratigraphical position - on the mineral bottom of the analysed palaeolake. It could be mostly the Bølling-Allerød age (Błaszkiewicz 2005, 2011 and quated literature). It developed around the initial, small and shallow water reservoirs on the surface of melting blocks of dead ice, The basal peat do not cover the whole floor but appear only in some areas. The distribution of it isn't ascertained in the deepest part of the reservoirs. The basal peat consists largely of Sphagnum peat, often poorly decayed, with well-preserved macroscopic plant remains, or of a highly decomposed from resembling coarse-detritus or mineral gyttja. Its thickness is highly diversified and ranges from $5 \mathrm{~cm}$ to $40 \mathrm{~cm}$ (reservoir No. 1), 5-16 cm (reservoir
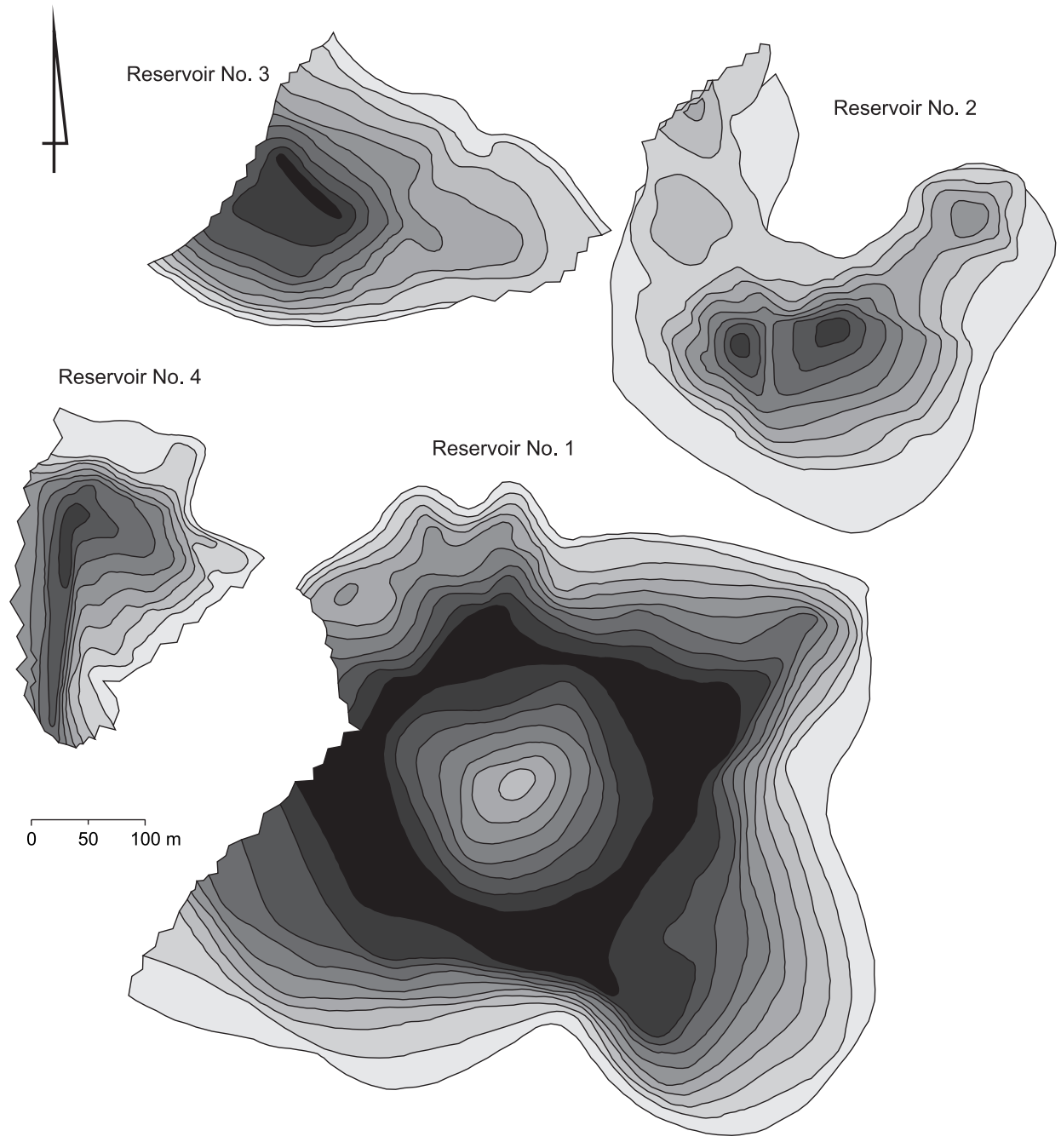

Fig. 2. The map of the reservoirs (palaeolakes) depth (in metres) and bottom morphology. 
No. 2), 5-25 cm (reservoir No. 3), and 10-20 cm (reservoir No. 4). The ceiling of biogenic matter sediments consists also of peat which covers the whole reservoir with a layer of variable thickness. The thickness of this peat ranging from 0.1 meter even to 4.7 meters (in the reservoir No. 2). Mostly the thickness is about 1.5-2.0 meters. This largely Carex and Sphagnum peat is characterized by varying phases of decomposition. The most top part of about 0.5 meter is highly sandy peat.

\section{Geochemical composition}

In order to determine the environment al changes in the Late Glacial and Early Holocene, biogenic sediments from the reservoir No. 1 was collected (drilling at site 18 Fig. 1C) with a thickness of $713 \mathrm{~cm}$ (Fig. 5) using manual Instorf sampler. The sandy bottom of the reservoir was reached. Because the main aim of the study is recognition of the environmental changes in the Late Glacial and Early Holocene and reconstruction of the conditions that prevailed in the initial period of melting buried dead ice., basal meter of sediments has been subjected to detailed analysis. The samples were taken from the core separately for the analysis of calcium carbonate content and for organic matter content. The content of $\mathrm{CaCO}_{3}$ has been indicated by using the Scheibler's method. Mineral particles has been calculated on the basis of loss-on-ignition (LOI) survey, due to heating at $550^{\circ} \mathrm{C}$.

The average $\mathrm{CaCO}_{3}$ content in the basal peat is $23.5 \%$ (Fig. 5). In basal peat directly overlying the

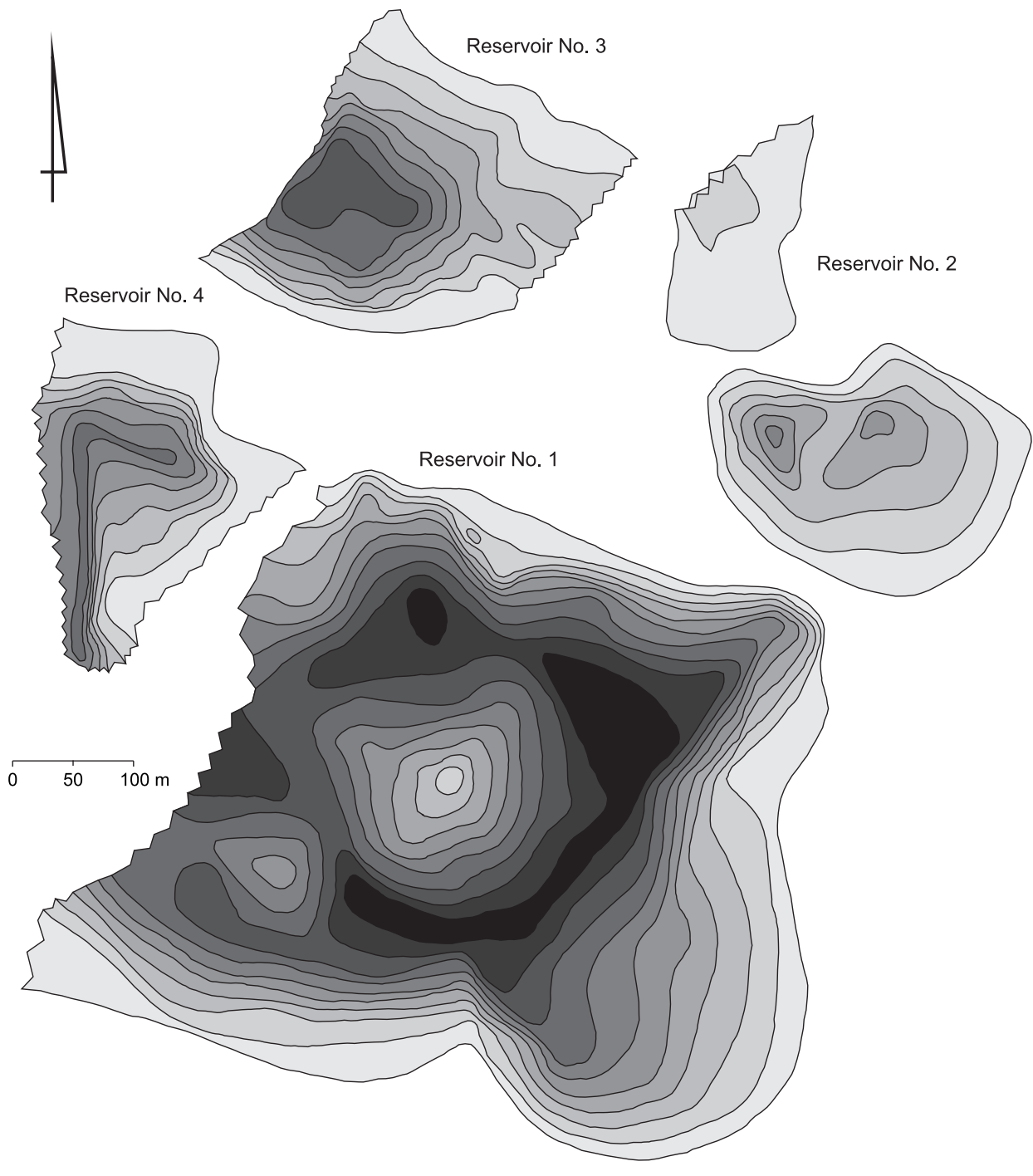

Fig. 3. The map of the gyttja thickness (in metres) in the the reservoirs (palaeolakes). 
sandy floor of the reservoir No. 1 there is $24.6 \%$ of $\mathrm{CaCO}_{3}$. Then it decreases to the amount of $12.6 \%$. After that it gradually increased to $36 \%$. Basal peat consist almost of organic matter. There is $5.5 \%$ of average of mineral matter. It increases from $2.85 \%$ to $8.7 \%$.

Gyttja is a deposit very rich in $\mathrm{CaCO}_{3}$. The average amount in studied profile of sediments is $84 \%$. Hence gyttja can be even classified as lacustrine chalk. The $\mathrm{CaCO}_{3}$ content increases from the $59 \%$ in gyttja in its layer overlying directly basal peat. At the depth $691 \mathrm{~cm}$ the amount of $\mathrm{CaCO}_{3}$ reaches $100 \%$ and then a bit decreased to $83-85 \%$.
The average amount of mineral matter in gyttia is similar to basal peat and it reaches $5.3 \%$. In gyttja directly overlying peat, the mineral matter content increased to $13 \%$ and then decreases. At a depth of $655-650 \mathrm{~cm}$ it vanishes completely.

Carbonate content index of sediments $\left(\mathrm{CaCO}_{3} / \mathrm{OM}\right)$ was calculated on the basis of geochemical analysis (Fig. 5). It provides a quantitative measure of sediment lithological variability (Wojciechowski 2000). High values of the index indicate increased dampness of climate, higher water levels, as well as changes in the depth of the reservoir, since the process of leaching cal-
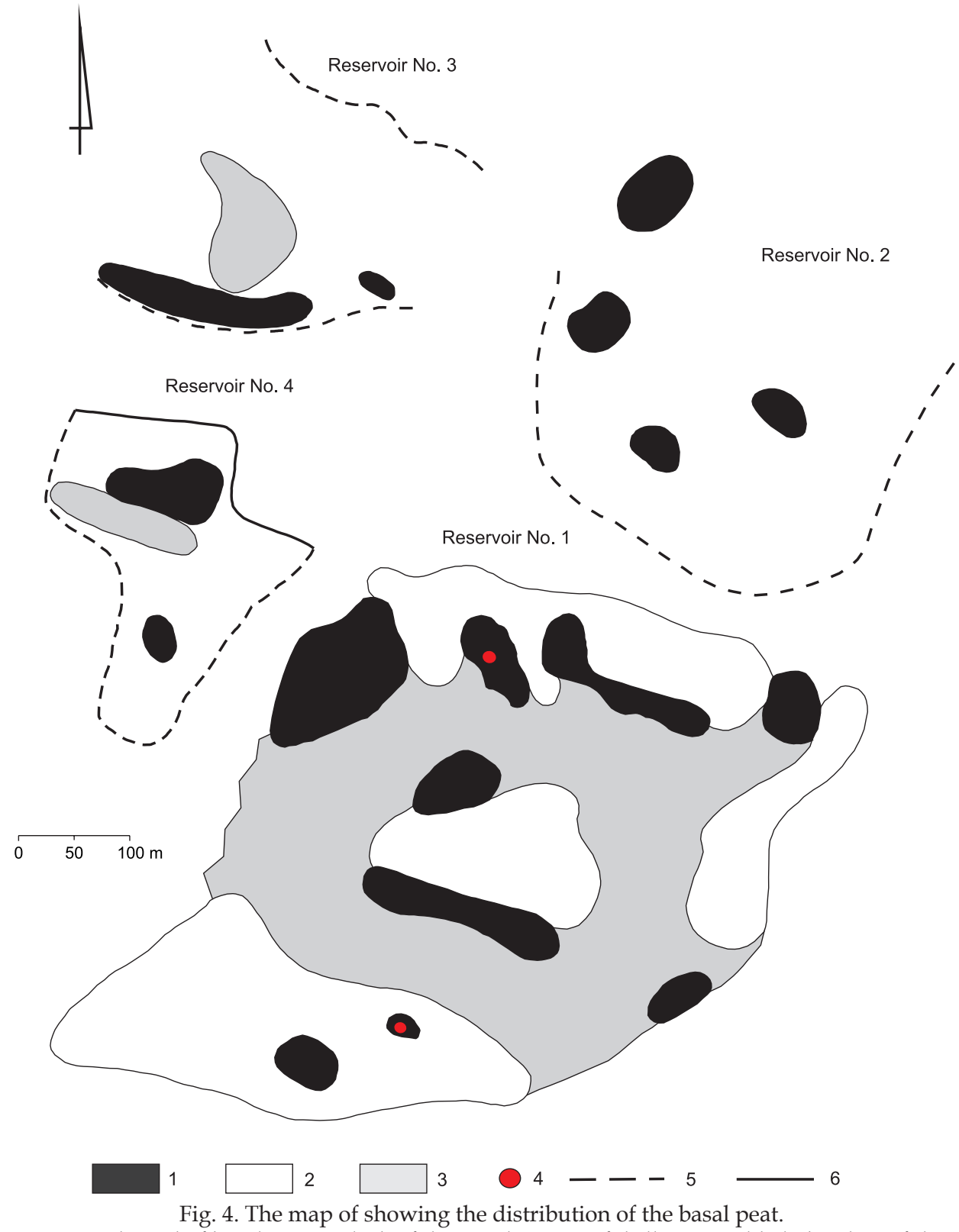

Reservoir No. 2
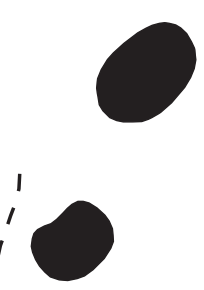

Fig. 4. The map of showing the distribution of the basal peat.

1 - basal peat, 2 - areas devoid of basal peat 3 - lack of data 4 - location of drillings, 5 - likely borders of the reservoirs, 6 ascertained shores of the reservoirs. 
cium carbonate depends on the humidity of the climate (Wojciechowski 2000). The average value of the $\mathrm{CaCO}_{3} / \mathrm{OM}$ index for all analysed deposits is equal 0.764 . It means that organic matter predominates over calcium carbonate. Organic matter predominates over calcium carbonate. $\mathrm{CaCO}_{3} / \mathrm{OM}$ index values range from 0.130 for the basal peat to 1.103 for gyttja. The dominance of $\mathrm{CaCO}_{3}$ over $\mathrm{OM}$ has been identified only in a few samples (at the depth of $69 \mathrm{~cm}-1.103,649$ $\mathrm{cm}-1.043,626 \mathrm{~cm}-1.002,612 \mathrm{~cm}-1.024,601$ $\mathrm{cm}-1.015)$ (69 cm depth $-1.103,649 \mathrm{~cm}-1.043$, $626 \mathrm{~cm}-1.002,612 \mathrm{~cm}-1.024,601 \mathrm{~cm}-1.015)$. Higher values of the $\mathrm{CaCO}_{3} / \mathrm{OM}$ index point at cooler periods because of higher input of $\mathrm{CaCO}_{3}$. The growth of $\mathrm{CaCO}_{3} / \mathrm{OM}$ index is visible at the end of Allerød and especially during the Younger Dryas (Fig. 5). However, high contribution of $\mathrm{CaCO}_{3}$ is also record during the phase of low water, especially in littoral zone, accumulated in the Allerød (approximately 11000-11800 lat BP) (Wojciechowski 2000).

\section{Palynological research}

The very first palynological research in Lubrza region (Western Poland) was carried out alongside archaeological excavations on site 42 (core L-33/2, location at Fig. 1C) (Okuniewska-Nowaczyk 2011a,b). Second core of biogenic matter (core LB 2013, Fig. 1C) taken in the reservoir No. 1 underwent also detailed palynological examination (Ratajczak-Szczerba et al., 2014). At each research site there were the presence of the basal peat. The $676-\mathrm{cm}$-thick core L-33/2 was collected in the southeastern part of an oval widening in the shore area of the reservoir (Fig. 6A). The samples for detailed analysis for the existence of sporomorphs was taken from the substratum sand with detritus, the basal peat 56.5 -cm-thick and the gyttja deposited on top of it were all analyzed for. The location of the second, 713-cm-thick core (LB 2013) for detailed scientific analyses was determined in the vicinity of the archaeological site no. 10 in the northern part of the reservoir with a steep slopes on it bottom close to the northern shoreline (Fig. 6B). The distance between the sampling locations of the cores is about 400 meters.

The accumulation of the sediments in both sites under study took place in the late glacial period; for the southern part of the reservoir it was probably earlier, i.e. in Bølling, and for the northern part - in Allerød, dated on the basis of the AMS-radiocarbon and palynological analysis. The genesis of the biogenic sedimentation were similar, although it began at a different time. After the ice sheet had retreated and when the climate conditions had improved, the melting of buried ice blocks and hydrogenic ice began. In the first phase a shallow depression was formed,

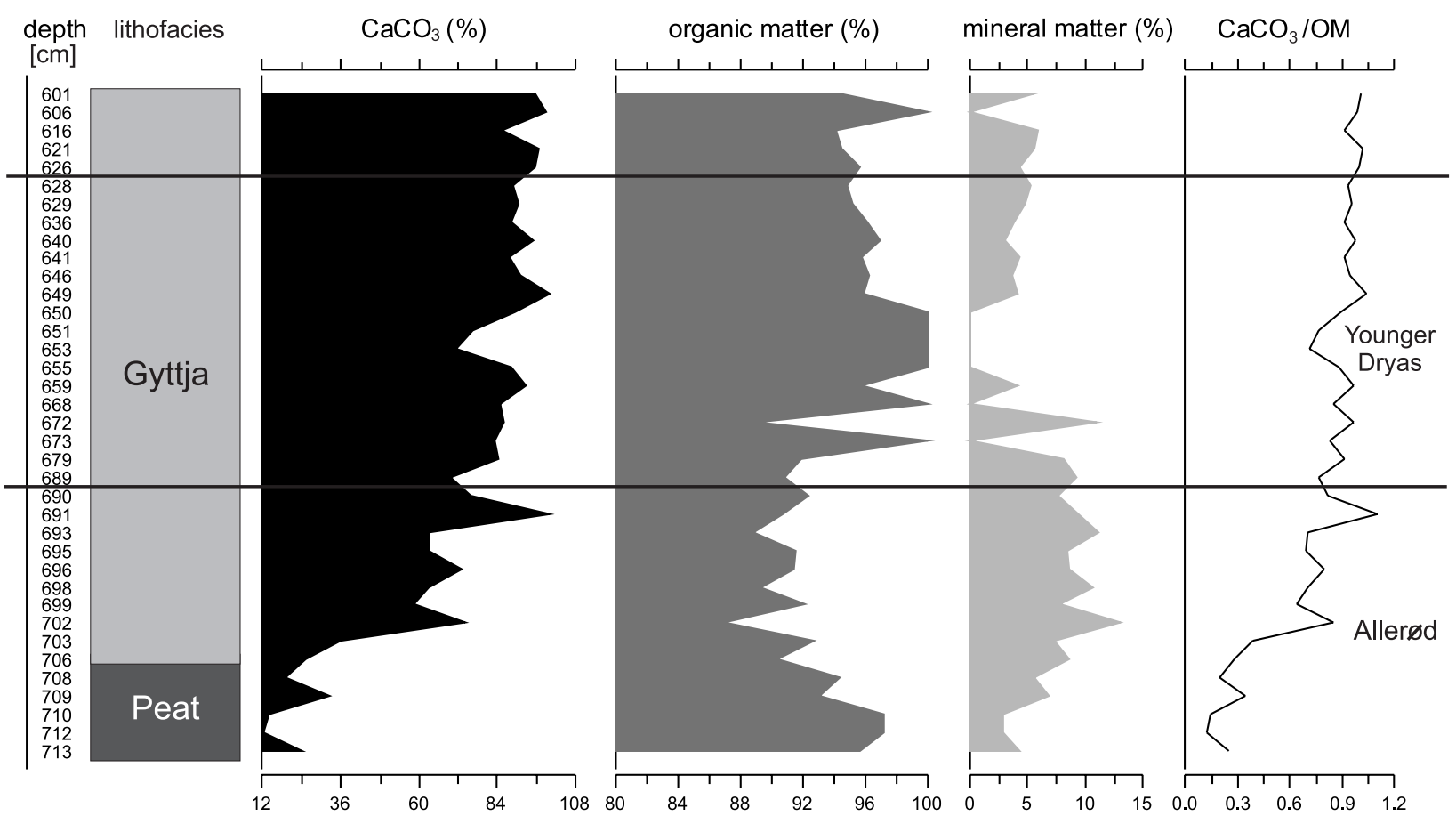

Fig. 5. Content of carbon dioxide and organic matter in the bottom part (713-600 m under ground level) of the site 18. 
where peat-forming plants developed and left a layer of peat. Further melting of the ice resulted in an increase in the depth of the lake and consequently in the accumulation of calcareous gyttja.

The records of the history of vegetation from the pre-Allerød periods point the open landscape
(Fig. 6A) in the research area. The conditions encouraged the development of heliophytes such as Juniperus, Artemisia and Helianthemum. Numerous areas were covered with patches of dwarf shrub tundra with Betula nana and Salix, probably Salix polaris. Locations dominated by Hippophä
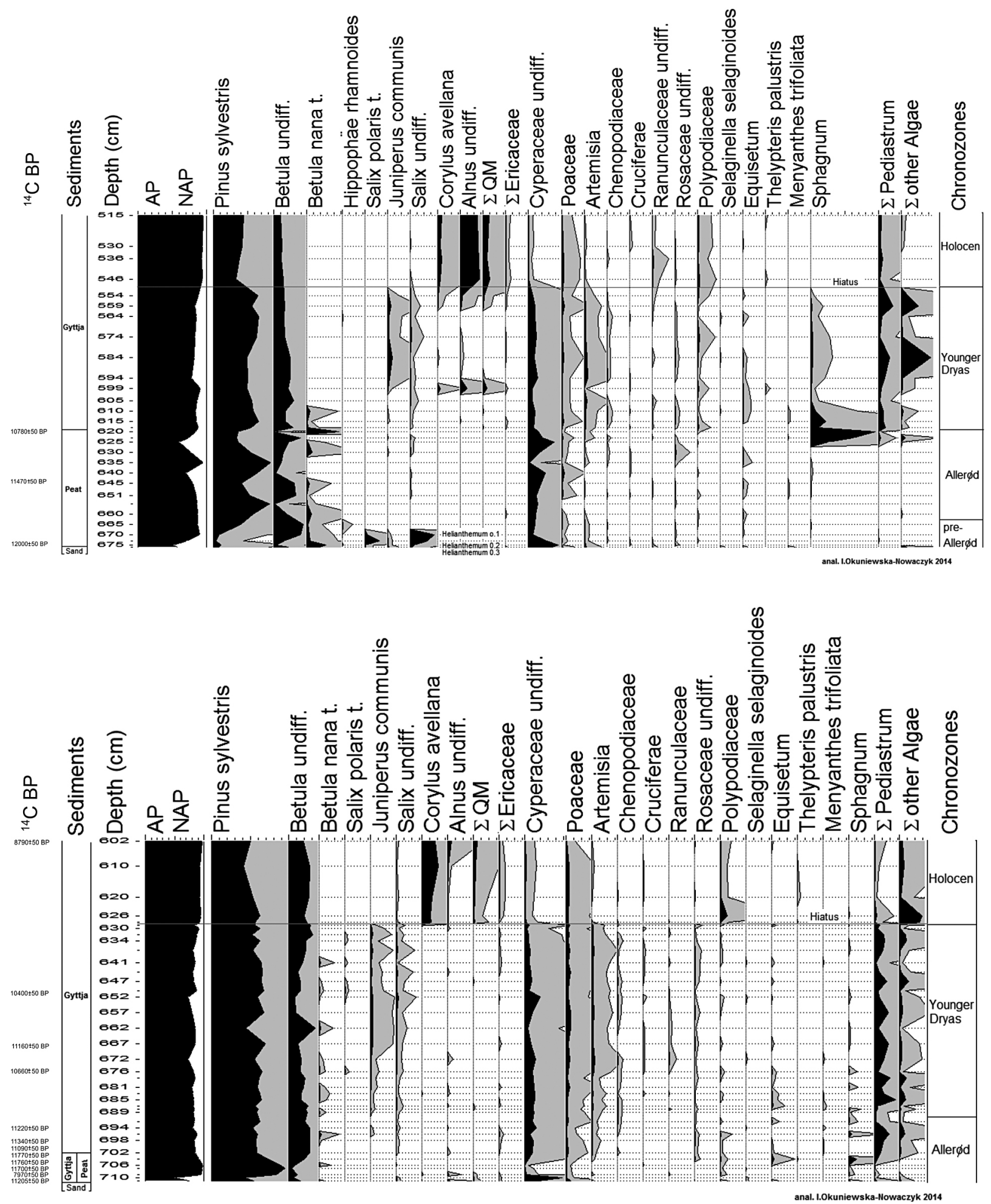

Fig. 6. Simplified pollen diagram (AP+NAP=100\%) of A. L-33/2, B. LB 2013. 
rhamnoides appear later. The immediate vicinity of the reservoir was dominated by the Cyperaceae, with records also of Menyanthes trifoliata and Equisetum.

The pollen image of Allerød is diversified (Fig. 6A, B). The fluctuating pollen curve might not only point to the sedimentation processes not running continuously, but also reflect the instability of the climate of that period. The history of the vegetation from pre-Allerød is recorded mainly in the basal peat in the core taken from the southern part of the reservoir. The vicinity of a lake surface and wind waves is recorded by the algae, such as Pediastrum, Botryococcus and Tetraedron genera. At the beginning, the area was dominated by not dense birch-pine forests, with pine-birch forests at a later stage and again birchpine forests locally dominated by Juniperus (probably Juniperus communis), which found favorable conditions for growth there, particularly at the kame nearby. The fact that the tree stand thinned out might be attributed to the drop of temperatures, which was a harbinger of the upcoming cooling of the climate.

The image of the Younger Dryas recorded in both cores demonstrates the heterogeneity of this period (Fig. 6B). The records show small initial presence of Juniperus in the landscape, its maximum proportion later and fluctuating values in the third phase. The presence of Artemisia follows a similar pattern. The thinning tree stands were conducive to aeolian processes. This is indicated by a significant proportion of silt in the palynological samples. The effects of the natural processes were intensified by the activity of humans settled (Federmesser and Swiderian societes) at the nearby kame. Pollen diagrams recorded both coal dust and numerous charred plant remains, which constitute traces of past fires.

Also, a gap in sedimentation was recorded at the beginning of the Holocene, which covered the entire Preboreal, and also part of the Boreal in the southern part of the reservoir (Fig. 6). This phenomenon evidence in plant macrofossil and charcoal analyses conducted by Kubiak-Martens (2015).

\section{Lithofacial analysis of a kame}

Investigated reservoirs surround the convex geomorphological feature. The kame consists of sand and gravel sediments. It is elongated landform, oriented from the north-west toward the south-east, perpendicularly to the axis and the edge of the channel. The east end of the form is connected to the III outwash level. The form is higher about 10 meters above the present surface of biogenic matter. The kame is largely built of such sediments on its surface as sand and silty sands, sporadically interbedded with gravel sands (Fig. 7). The sediments are mostly of massive structure (Fm, Sm, S(G)m). Some of them is horizontally interbedded or they are low angle laminated (SGl, Sl). The thickness of sediments layer is not big. Mostly massive sands and massive silty sands prevail alternately. A massive structure can be an evidence of very short transportation period, and together with the size of grains - low energy of the depositional environment. However, alternate layers of different sands point of the high variability of deposition and decreasing share of water. The ground sediments were examined at three sites (Fig. 7).

Site 1: Mean grain size $(\mathrm{Mz})$ of all deposits about 2.7 phi $(0.154 \mathrm{~mm})$ indicates admixture of fine grains and a transport in suspension (Fig. $8)$. Sediments are poorly and moderately sorted ( $\delta$ 0.34-0.178 phi). Quartz grains are mostly semi-angular ( $\beta 47.4 \%)$. Index of quartz grain abrasion Wo equal 1025 points that there is a prevalence of mature quartz grains, with blunt quoins and edges. It indicates a transport in water long enough to round off quartz grains. High value $(23 \%)$ of $\gamma$-type quartz grains (rounded) means that some amount if sediment can be supply by wind. In this research site, at the bottom of deposits there are alternate massive sands $(\mathrm{Sm})$, massive silty sands (SFm), massive gravely sands (SGm) and low-angle cross laminated gravely sands (SGl). In the top of sediments there are 0.5 meter thick massive large-grained gravely sands $(\mathrm{S}(\mathrm{G}) \mathrm{m})$. Sediments like Sm, SGm, SFm are typical for fluvioglacial environment. Deposits like $\mathrm{S}(\mathrm{G}) \mathrm{m}$ for gravely bottom braided river and also for the distal position of the sandur fan. We can treated this as gravely alluvium, accumulated from layerd alluvion in the vicinity of ice (blocks of dead ice or active ice). Massive sand (Sm), massive silty sands (SFm) are sandy alluvium that was accumulated in flat bottom melting river with low-energy deposition from channel flow or layerd alluvion. 

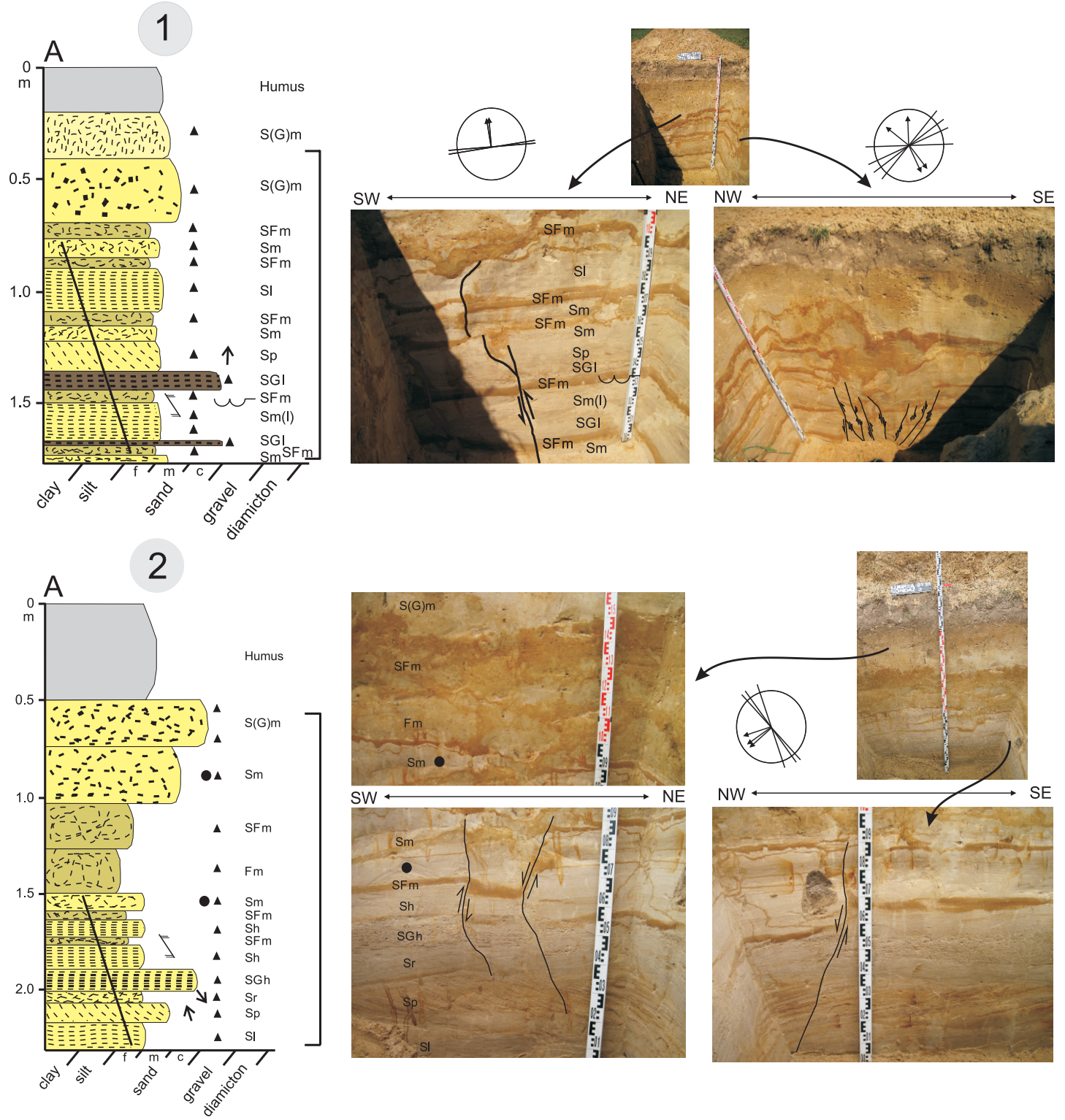

\section{3}
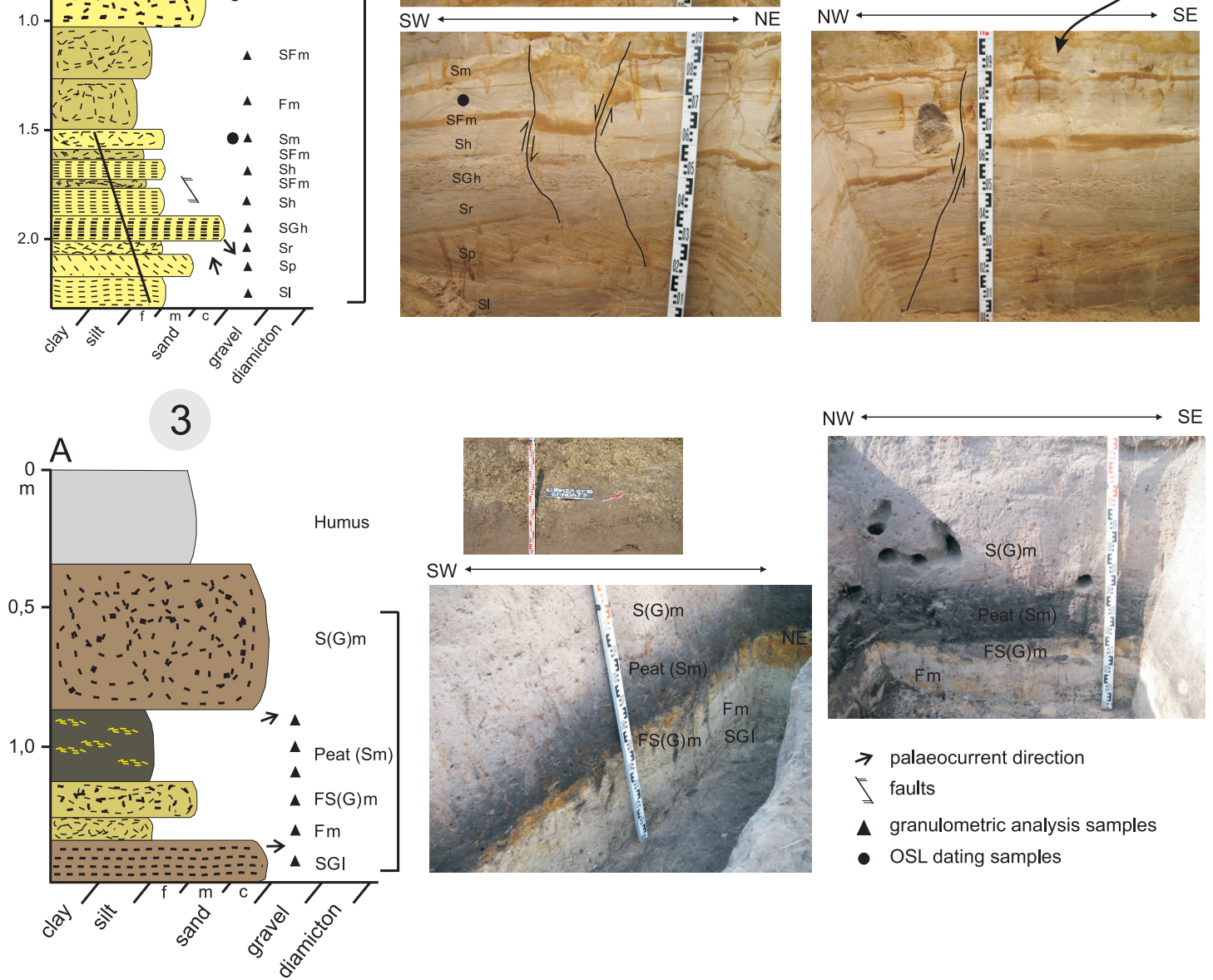

$\rightarrow$ palaeocurrent direction

$\searrow$ faults

A granulometric analysis samples

- OSL dating samples

Fig. 7. Geological structures of the kame deposits $(1,2)$ and the shore line of the palaeolake (3). Schematic sedimentological logs. 
Site 2: Mean grain size $(\mathrm{Mz})$ of all deposits is 2.36 phi $(0.195 \mathrm{~mm})$ indicates that gravely sand material was transported by saltation (Fig. 8). Sediments are moderate sorted ( $\delta$ from 0.5 to 1.6 phi). Sands laminated horizontally (Sh), horizontaly laminated sand with gravel (SGh) and silty sands (SFh) also laminated horizontaly are distributed alternate. However, their rhythm is finer. Series Sh, SFh or SFm establish brief sedimentary cycles from low-energy tractional current (Sh) and deposition from suspension in almost stagnant water (SFh, SFm). Slightly inclination of deposits towards SW indicates gentle slope of depositional surface. At the bottom there are low-angle cross-laminated sands (Sp, $\mathrm{Sl})$ and rip- ple-cross lamination (Sr). Good sorting is an effect of long transport and stabilized regime. Over deposits described above, there are fine-grained sands and silts, mostly massive indicating the transport in suspension during very slow flow. It is confirmed by very poor sortation $(\delta 1.18-1.8$ phi). The transport should be very short or the amount of water in deposits was very small. The most upper 1 meter of deposits is built from medium- and fine-size grained sand with admixture of large-grained, massive sands $(\mathrm{Sm}, \mathrm{S}(\mathrm{G}) \mathrm{m})$. Such sediments point on slope washes fine- and medium-grained with admixture of gravel fraction deposits. Semi-angular of $\beta$-type are most numerous among quartz grains. Two OSL sam-
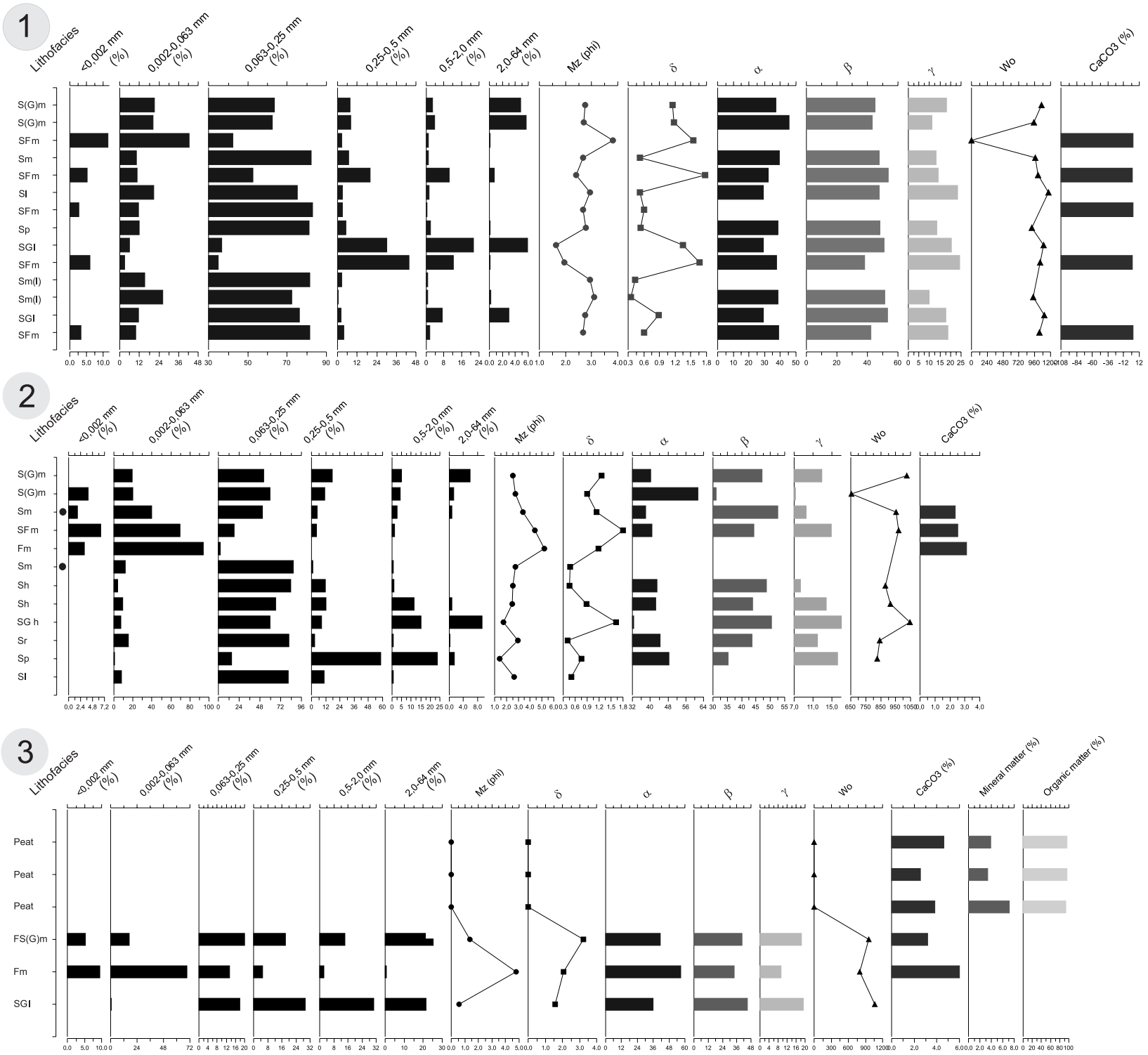

Fig. 8. The grain-size composition of deposits and content of carbon dioxide in the kame $(1,2)$ and in the palaeolake shore line. $\mathrm{Mz}$ - mean grain size, defined as the arithmetic mean of 3 percentiles: $\mathrm{d}_{16^{\prime}} \mathrm{d}_{50^{\prime}} \mathrm{d}_{84^{\prime}}$ according to the method of Folk and Ward (1957). 
ples were taken from massive sand at the depth:

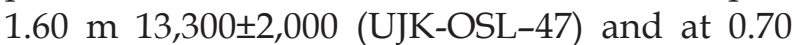
m 10,700 $\pm 1,600$ (UJK-OSL-46) (Fig. 7). The OSL dates were received from the deposits that suggest the end of the deposition of the fluvioglacial sediments. Diagnostic features of deposits point sedimentary cycles from low-energy tractional current and deposition from suspension, sometimes long transport and stabilized regime. According to the OSL dates it happened in the end of the Old Dryas and at the beginning of Bølling and in Allerød, at least at the beginning of the Younger Dryas, as a result of melting of the ice blocks left by retreated ice sheet.

Site 3: Mean grain size $(\mathrm{Mz})$ of all deposits is from 0.56 phi $(0.678 \mathrm{~mm})$ - big grains, moved in fraction, to 4.76 phi $(0.037 \mathrm{~mm})$ - fine grains, transported in suspension (Fig. 8). This research site is located along the fossil palaeolake shore and such data indicates mixing of water in the breaker zone because of wind waves action. Sediments are poorly and very poorly sorted. There are more quartz grains of a-type - angular ones. It can be caused by intensive weathering along the shore line. The mineral deposits are overlyied by peat. It consists of $93-96 \%$ from organic matter.

The $\mathrm{CaCO}_{3}$ content in investigated deposits are not high (Fig. 8). Fine-grained sediments, i.e., sands, silts and silty sands contain $2-3 \% \mathrm{CaCO}_{3}$; the compound is absent in coarse-grained sediments, having been removed in the course of deposition In large-grained sediments there is lack of $\mathrm{CaCO}_{3}$. Probably it was carried out from deposit during transportation. In peat there is only 3.0-6.0\% of $\mathrm{CaCO}_{3}$.

Deposits lying below a depth of $0.70 \mathrm{~m}$ are deformed by numerous cracks in the form of normal and reversed faults, which brought about considerable disturbances in the primary sedimentary sequence of the deposits originally building the feature (Fig. 7). Such types of deformations present in the marginal parts of kames are believed to be related to the loss of ice support (Bartkowski 1963, Rotnicki 1976, Dadlez, Jaroszewski 1994), whereas faults and deformations in the inner parts of kames have been interpreted as a result of the collapse of sediments into the spaces that remained following the melting of buried dead ice deposited under kame deposits (Karczewski 1971, Klajnert 1978).

\section{Archaeological research}

On the sandy kames, just next to former reservoirs, five Late Palaeolithic sites were located, within the area of ca. $1 \mathrm{~km}^{2}$.

The largest one (site no. 42, Fig. 1C) yielded over 10,000 flint artefacts affiliated to two taxonomic units, namely the Federmesser and Swiderian cultures (Kabaciński, Sobkowiak-Tabaka 2010). The first one developed generally on the territory of present-day Poland in the Allerød (Greenland Interstadial - GI - 1c1 - 1a; circa 13,550 - 12,750 years cal b2k) and in the initial phases of the Younger Dryas - GS-1, circa 12,750 - 11,700 years cal b2k (Litt et al. 2001, Lowe et al. 2008). The second one existed between mid-Younger Dryas and the beginning of Preboreal (Sobkowiak-Tabaka 2011:112). Additionally, 1000 Mesolithic artefacts, dated to the Early Holocene, were found.

Excavations at a neighbouring site 11 (Fig. 1C), located approximately $400 \mathrm{~m}$ to the east, produced the remains of the Swiderian occupation along with a few artefacts attesting to the penetration of the area by Mesolithic communities (Kabaciński, Sobkowiak-Tabaka 2011).

On the other side of the Niesulicki Channel, about $100 \mathrm{~m}$ to NW from site 42 (Fig. 1C), a single backed point was found, most likely related to the activity of the Federmesser community from a camp at site 42 (Pyżewicz et al. 2008).

At site 10 (Fig. 1C), on a sandy kame, ca. 500 $\mathrm{m}$ to the north from site 42 , remains of two Late Palaeolithic campsites were discovered. The first one, consisting of five flint concentrations (ca. 1150 items), a hearth (?) with several fine, burnt animal bones, is attributable to the Federmesser Culture, and the other one to the Swiderian Culture (ca. over 2800 items). Radiocarbon determination of burnt bones gave the result $11300 \pm 60$ BP (Poz-65348).

About 200 Swiderian artefacts were recovered from the northernmost site in the investigated area - site 37 (Fig. 1C). A few Mesolithic implements, evidencing the penetration of the area in the Early Holocene, were also found. In the course of excavations carried out on the northern shore of the reservoir no. 2 (site 38), no Palaeolithic or Mesolithic artefacts or traces of occupation were registered.

Remains of a number of functionally diverse sites, namely single finds, domestic units and 
workshops confirm relatively intensive occupation on the kames features neighbouring areas of the palaeoreservoirs. Both geological and palaeoenvironmental conditions were suitable for human occupation in the Late Palaeolithic and Mesolithic (albeit to a lesser extent), not only because of the vicinity of water reservoirs but also the presence of moraine hills cut by outwash valleys and channels (Bratlund 1999, Jasiewicz, Sobkowiak-Tabaka 2015, Spiess 1979). Such geodiversity was favourable for Late Palaeolithic and Mesolithic hunter-gatherer societies, living mostly on hunting and fishing. Human impact on the investigated area is also visible in the sediments recorded in the reservoir No. 1. Charcoals recovered from the level related to the Federmesser occupation come most probably from campfires, while charred remains of sedges and peat moss recorded in the level related to the Swiderian settlement indicate perhaps intentional shaping of the shoreline. It is highly possible that changes in the settlement intensity throughout the analysed area, i.e., fairly intensive Mesolithic settlement on the south side of the reservoir 1 and its virtual absence on the northern side, are directly related to a different evolution in its various parts. The lack of settlement on the northern shore of reservoir No. 2 might have been caused by its poor utility (a wide shoreline restricting the access to water).

\section{Conclusions}

The subglacial trough was formed during the Last Scandinavian Ice Sheet retreat on the Pomeranian Phase Line. The bottom morphology of the palaeolakes consist of several depressions. Nowaczyk (1994) hypothesized that subglacial channels were preserved by dead-ice blocks. They get into the channels because of decay of the tunnel ceiling. Subsequent covering by sandy-gravely fluvioglacial deposits preserved the dead-ice blocks, and protect them from heating and as a consequence from quickly melting. Only the climate warming in Bølling-Allerød interval and in Preboreal caused very quickly melting of buried dead-ice blocks. Other hypothesis of the presence of the depressions in the subglacial channels claims that these features on the subglacial channels bottoms were the effect of erosion caused by water under the hydrostatic pressure
(Błaszkiewicz 2011, Kordowski et al. 2014). The subglacial channel could be filled also by deadice blocks which could have hydrogenic character that was caused by super-cooling phenomena (Błaszkiewicz 2011). The analysed subglacial trough together with dead-ice blocks which preserved it, was filled by fluvioglacial sandy-gravely deposits. In the investigated course of the Jordanow-Niesulice glacial trough there are at least two separate reservoirs: No. 1, 3 and 4 could be the same palaeolake, but this hypothesis should be confirmed by further research and reservoir No. 2 which was completely independent lake. The morphology of the reservoirs bottom is diversify by several depressions, the effects of buried dead-ice blocks presence. The depth of the depressions is more than 10 meters. Melting of the buried ice in the subglacial channel began the period of the full development of the lake basin. However, probably it took place in two different time. The basal peat which was found on the bottom of palaeolake was dated ${ }^{14} \mathrm{C}$ and palynologicaly. Mostly, the melting began in the Allerød interval. In the southern part of the reservoir No. 1 the palynological evidences suggest that it could be even earlier, in the Bølling. After melting of the buried ice development of the lake basins began and deposition of lacustrine sediments, mostly by gyttja. In the reservoirs No. 1, 2 and 4 there is a prevalence of the same types of gyttja: silty-clay, calcareous, detritus and mineral, gray, beige or olive. Only in the reservoir No. 2, gyttja is brown, rusty and pink, probably the effect of red alga Rhodophyta. There is a kem between the reservoirs No. 1 and 2. This the form where people settled during Late Palaeolithic. The feature was formed during the fluvioglacial flow over the dead-ice blocks and deposition of sand and gravel in the cracks and crevasses. Fine deposits (Fm, Fh) were accumulated after cessation of flow, from suspension in small ponds on the surface. These small pond probably functioned between and under the buried ice blocks. Small thickness of layers suggests a great diversity of sedimentation conditions: alternately from flowing water and in water of waning flow or even in stagnant water. Later, in the second period of feature development there took place periodic redeposition of supraglacial large grain sediments, that means direct melting of the buried ice blocks. During that time large grain sands with gravels, 
massive were deposited, very often as a result of mass movement. The source of water for these processes was in ice blocks which were stuck in the investigated trough. The development of the kame feature ende in the Bølling-Allerød interval, at leats at the beginning of the Younger Dryas (OSL dates 13,300 $\pm 2,000$, UJK-OSL-47 and 10,700 $\pm 1,600$, UJK-OSL-46) These processes were probably synchronous with the buried ice blocks melting. In the vicinity of the reservoirs, especially on the kame feature and around the palaeolakes form the people settled from the late Late Palaeolithic. There are known eight archaeological sites (Fig. 1C). The artefacts affiliated to the Federmesser and Swiderian cultures were found. They were dated to the Allerød and the Younger Dryas the first one, and the second one between mid-Younger Dryas and the beginning of Preboreal. The artefacts came from the Mesolithic communities were dated to the Early Holocene. According to archaeological investigation diversified geology, geomorphology and land cover mostly by birch-pine, later pine-birch and again birch-pine forests were favourable for settlement in Late Glacial and beginning of Holocene.

\section{Acknowledgment}

This research was supported by Grant for Scientific Research of National Science Centre: No. DEC-2011/01/D/HS3/04134, the project leader: dr Iwona Sobkowiak-Tabaka. We would like to thank that Reviewer for good, kind and valuable guidance.

\section{References}

Bartkowski T., 1963. Deglacjacja arealna - zasadniczy typ deglacjacji na obszarach nizinnych. Pr. Kom. Geogr.-Geol. Wydz. Mat.-Przyr. PTPN 70, 3: 338-347.

Berglund B.E., Ralska-Jasiewiczowa M., 1986. Pollen analysis and pollen diagrams. In: Berglund B.E. (ed.) Handbook of Holocene Palaeoecology and Palaeohydrology. Wiley, Chichester, p. 483.

Birks H.J.B., Birks H.H., 2004. The rise and fall of forest. Science 305: 484-485.

Błaszkiewicz M., 2005. Późnoglacjalna i wczesno holoceńska ewolucja obniżeń jeziornych na Pojezierzu Kociewskim (wschodnia cześć Pomorza). Prace Geograficzne 201: $1-192$.

Błaszkiewicz M., 2011. Timing of the final disappearance of permafrost in the Central European Lowland as reconstructed from the evolution of lakes in N Poland. Geologial Quaterly 55(4): 361-374.
Bratlund B., 1999. A Survey of the Ahrensburgian Faunal Assemblage of Stellmoor. In: Kozłowski S.K., Gurba J., Zalizniak L. (eds), Tanged Point Cultures in Europe. Read at the International Archaeological Symposium Lublin, September, 13-16, 1993. Maria Curie-Skłodowska University Press, Lublin: 47-59.

Chmal R., 2003. Objaśnienia do Szczegółowej Mapy Geologicznej Polski, Arkusz Toporów (501). PIG, Warszawa: $1-49$.

Dadlez R., Jaroszewski W., 1994. Tektonika. Wyd. Nauk. PWN, Warszawa.

Folk R. L., Ward W. C., 1957. Brazors River bar: a study in the significance of grain size parameters, Jour. of Sedim. Petrol, 27, 1.

Jasiewicz J., Sobkowiak-Tabaka I., 2015. Geo-spatial modelling with unbalanced data: modelling the spatial pattern of human activity during the Stone Age, Open Geosciences.

Kabaciński J., Sobkowiak-Tabaka I., 2010. Between East and West - a new site of the Federmessergruppen in Poland. Quartär 57: 139-154.

Kabaciński J., Sobkowiak-Tabaka I., 2011. Schyłkowy paleolit i mezolit. In: J. Kabaciński, I. Sobkowiak-Tabaka (eds), Materiaty do wczesnych pradziejów Zachodniej Wielkopolski. Osadnictwo pradziejowe i wczesnośredniowieczne w Lubrzy. Ratownicze badania archeologiczne Instytutu Archeologii i Etnologii PAN, Oddziat w Poznaniu III. Instytut Archeologii i Etnologii PAN, Poznań: 21-28.

Karczewski A., 1971. Zmienność litologiczna i strukturalna kemów Pomorza Zachodniego a zagadnienie ich klasyfikacji. Pr. Kom. Geogr.-Geol. Wydz. Mat.-Przyr. PTPN 11, 3: 3-57.

Klajnert Z., 1978. Zanik lodowca warciańskiego na Wysoczyźnie Skierniewickiej i jej północnym przedpolu. Acta Geogr. Lodz. 38.

Kordowski J., Błaszkiewicz M., Kramkowski M., Słowiński M., Tyszkowski S., Brauer A., Brykała D., Gierszewski P., Lamparski P., Lutyńska M., Mirosław-Grabowska J., Noryśkiewicz A.M., Obrembska M., Ott F., Wulf S., Zawiska I., 2014. Charakterystyka środowisk de pozycyjnych Jeziorna Czechowskiego i jego otoczenia, Landform Analysis 25: 55-75

Krygowski B., 1964. Graniformametria mechaniczna, teoria, zastosowanie. PTPN, Prace Komisji Geograficzno - Geologicznej 2 (4): 1-112.

Kubiak-Martens L., 2015. Plant macrofossils from core LB13 taken in the vicinity of the Final Paleolithic site in Lubrza, western Poland. I. Sobkowiak-Tabaka (executive) Project DEC-2011/01/D/HS3/04134, Późnoglacjalne społeczności łowiecko-zbierackie Pojezierza Lubuskiego. Chronologia, systematyka, podstawy utrzymania.

Latałowa M., van der Knaap W.O., 2006. Late Quaternary expansion of Norway spurce Picea bies (l) Karst. in Europe according to pollen data. Quaternary Science Reviews 25: 2780-2805

Litt T., Brauer A., Goslar T., Merkt J., Bałaga K., Müller H., Ralska - Jasiewiczowa M., Stebich M., Negendank J.F.W., 2001. Correlation and synchronisation of Late Glacial continental sequences in northen central Europe based on annually laminated lacustrine sediments. Quaternary Science Review 20: 1233 - 1249.

Lowe J.J., Rasmussen O., Björck S., Hoek W.Z., Steffensen J.P., Walker M.J.C., Yu Z.C. and the INTIMATE group. 2008. Synchronisation of palaeoenvironmental events in the North Atlantic region during Last Termination: a re- 
vised protocol recommended by the INTIMATE group. Quaternary Science Review 27: 6-17.

Nowaczyk B., 1994. Wiek jezior i problemy zaniku brył pogrzebanego lodu na przykładzie sandru Brdy w okolicy Charzykowy, AUNC, Geografia 27: 97-110.

Okuniewska-Nowaczyk I., 2011a.Badania palinologiczne. In: J. Kabaciński/ I. Sobkowiak-Tabaka (eds.), Materiały do wczesnych pradziejów Zachodniej Wielkopolski. Osadnictwo pradziejowe i wczesnośredniowieczne w Lubrzy. Ratownicze Badania Archeologiczne, Instytut Archeologii i Etnologii PAN, Oddział w Poznaniu III (Poznań 2011): 263-275.

Okuniewska-Nowaczyk I., 2011b. Wiek torfów bazalnych w Lubrzy w świetle datowń palinologicznych i radiowęglowych. In: J. Kabaciński/ I. Sobkowiak-Tabaka (eds.), Materiały do wczesnych pradziejów Zachodniej Wielkopolski. Osadnictwo pradziejowe i wczesnośredniowieczne w Lubrzy.

Płochniewski Z., 1986. Hydrogeologia i geologia inżynierska. Wydawnictwo Geologiczne, Warszawa: 1-124.

Podbielkowski Z., 1985. Glony. Wydawnictwo Szkolne i Pedagogiczne, Warszawa.

Pyżewicz K., Rozbiegalski P., Skorupka T., Dmochowski P., 2008. Dwa odosobnione znaleziska tylczaków schyłkowopaleolitycznych z Wielkopolski i Kujaw. Wielkopolskie Sprawozdania Archeologiczne 9: 13-24.

Racinowski R, Szczypek T., 1985. Prezentacja i interpretacja wyników badań uziarnienia osadów czwartorzędowych. Skrypty Uniwersytet Ślaski 359: 1-143.

Ratajczak-Szczerba M., Sobkowiak-Tabaka I., Okuniewska-Nowaczyk I., 2014. Morfologia dna i osady denne ko- palnego zbiornika $\mathrm{w}$ rynnie jordanowsko-niesulickiej koło Lubrzy, Pojezierze Lubuskie, Studia Limnologica et Telmatica 8(2): 71-80.

Rotnicki K., 1976. The theoretical basis for and a model of the origin of glacitectonic deformations. Quaetr. Geogr. 3: 103-139.

Sobkowiak-Tabaka I., 2011. Społeczności późnego paleolitu w dorzeczu Odry. Instytut Archeologii i Etnologii PAN, Poznań.

Spiess A.F., 1979. Reindeer and Caribou Hunters. An Archaeological Study. Academic Press, New York.

Starkel L., 2002. Younger Dryas-Preboreal transition documented in the fluvial environment of Polish rivers. Global and Planetary Changes 35: 157-167

Willis K.J., van Andel T.H., 2004. Trees or no trees? The environments of central and eastern Europe during the Last Glaciation. Quaternary Science Reviews 23: 2369-2387

Wojciechowski A., 2000. Zmiany paleohydrologiczne w środkowej Wielkopolsce w ciagu ostatnich 12000 lat w świetle badań osadów jeziornych rynny kórnicko-zaniemyskiej. Wydawnictwo Naukowe UAM.

Zernitskaya V., Stancikaite M., Vlasov B., Seiriene V., Kisieliene D., Grygus G., Skipityte R., 2014. Vegetation pat tern and sedimentation changes in the cnotext of the Lateglacial climatic events: Case study of Saroje Lake (Eastern Belarus). Quaternary International 1-13. Online: http:// dx.doi.org/10.1016/j.quaint.2014.06.045

Zieliński T., 1992. Moreny czołowe Polski pótnocno-wschodniej - osady i warunki sedymentacji. Prace Naukowe Uniwersytety Śląskiego, 1325. 